Article

\title{
Sustainable Management of the Red Palm Weevil: The Nexus between Farmers' Adoption of Integrated Pest Management and Their Knowledge of Symptoms
}

\author{
Hazem S. Kassem ${ }^{1,2, *(\mathbb{C}}$, Bader Alhafi Alotaibi ${ }^{1} \oplus$, Ali Ahmed ${ }^{1}$ and Fahd O. Aldosri ${ }^{1}(\mathbb{C}$ \\ 1 Department of Agricultural Extension and Rural Society, King Saud University, Riyadh 11451, Saudi Arabia; \\ balhafi@ksu.edu.sa (B.A.A.); alisalihe33@gmail.com (A.A.); fadosri@ksu.edu.sa (F.O.A.) \\ 2 Department of Agricultural Extension and Rural Society, Mansoura University, Mansoura 35516, Egypt \\ * Correspondence: hskassem@ksu.edu.sa; Tel.: +966-581045671
}

Received: 26 October 2020; Accepted: 18 November 2020; Published: 19 November 2020

\begin{abstract}
The red palm weevil (RPW) (Rhynchophorus ferruginous) is one of the most serious pest insects threatening the sustainability of the date palm sector (Phoenix dactylifera L.). Nevertheless, a gap exists in the body of knowledge regarding patterns in farmers' adoption of integrated pest management (IPM) for RPW control and how their knowledge of RPW symptomology influences IPM adoption. Data were collected using structured questionnaires from 183 palm growers in Al-Ahsa Governorate, Saudi Arabia. The results indicate that most farmers had insufficient knowledge to visually diagnose RPW symptoms and damage. Farmers moderately adopted preventive measures recommended for protection from RPW infestation. Only $13.11 \%$ of the farmers exhibited a high rate of adoption of pest management practices for RPW control and eradication. The findings revealed a strong positive association $(0.8, p<0.01)$ between the knowledge level regarding symptoms and IPM adoption level, whereby the respondents with more knowledge of RPW symptoms showed a higher level of adoption in all IPM categories. This study contributes to the development of our understanding of the social behaviors and risks associated with RPW. This might enhance the quality of awareness campaigns and extension programs and assist in developing a visual inspection protocol for RPW infestation for farmers.
\end{abstract}

Keywords: red palm weevil (RPW); farmers; adoption; knowledge; integrated pest management (IPM); sustainable agriculture

\section{Introduction}

Date palm (Phoenix dactylifera L.) is an important fruit crop in arid regions, such as the Arabian Peninsula, North Africa, and the Middle East [1]. Saudi Arabia ranked third after Egypt and Iran in total date production in 2018, contributing $15 \%$ of all dates produced globally [2]. Based on a report from Saudi Arabia's Ministry of Environment, Water, and Agriculture [3], total date production was approximately 1.3 million tons and there are over 30 million date palm trees in the country, covering an area of 107,000 (ha). The date serves as an essential source of essential nutrients, especially dietary potassium $[4,5]$. Furthermore, it features several medicinal qualities, namely, anti-fungal, antibacterial, anti-tumor, anti-ulcer, and immunomodulatory properties [6]. Although the number of palm trees in Saudi Arabia has increased, their average yield is lower than other date-producing countries [7] due to the low yield potential of certain varieties, insect pests and plant diseases, and poor management practices $[8,9]$.

Insect pests are a significant production constraint for palm dates in Saudi Arabia. The red palm weevil (RPW) (Rhynchophorus ferruginous (Olivier), Coleoptera: Curculionidae) has become the most 
devastating pest affecting date palm trees in several regions of the world, including Saudi Arabia [9-11]. The RPW was first reported in the eastern region of Saudi Arabia in the mid-1980s [1] and then spread to other areas through infested planting material being transported for farming and landscape gardening $[8,12,13]$. Globally, RPWs affect nearly 40 palm species belonging to 23 different genera in more than 60 countries $[6,14]$. In Saudi Arabia, the estimated number of date palms infested by RPW has reached of 80,000 palms, costing over USD 8.69 million in economic losses for its management and eradication $[9,15]$. Therefore, serious and prompt action to eradicate RPWs should be implemented to enable the survival of palm trees and support the livelihood of palm growers $[16,17]$.

Worldwide, the control of RPWs primarily relies on the use of synthetic pesticides [18]. However, pesticides do not effectively manage RPWs, endanger biological diversity, and deteriorate environmental quality $[8,18,19]$. Furthermore, due to increased concerns about the environmental and human health side effects of pesticides, there is growing demand to implement integrated pest management (IPM) [20]. Currently, IPM is the primary paradigm in plant protection, approved by all stakeholders in the agricultural value chain to maintain pesticides and other interventions at levels that are ecologically and economically justified [21-23]. The current RPW IPM strategy is comprised of periodic field surveys for detecting infestations, applying phyto-sanitation and agro-techniques (i.e., palm and field sanitation, elimination of hidden breeding sites, including abandoned date plantations, and palm injury prevention), preventive and curative chemical treatments, eradicating severely infested palms, implementing quarantine measures, and education and training $[1,6,16]$. Undoubtedly, implementing an IPM strategy is not easy. Date palm growers are faced with various challenges in many countries, including a lack of efficient early detection methods, weak enforcement of quarantine measures, and uncontrolled movement of infested trees; an inability of biocontrol agents being efficiently delivered and sustained in field conditions; insufficient understanding of RPW field behavior among farmers; and a lack of knowledge of symptoms and adoption of management practices by farmers $[16,24,25]$.

Although many RPW preventive and curative measures are in place today, the failure to manage RPWs in most countries can be attributed mainly to a lack of awareness, knowledge, and adoption of these measures, as well as the weakness of systematic and coordinated control actions or management strategies that involve all stakeholders [16,26]. To effectively implement an IPM program for RPWs that suits small-scale farmers in developing countries, such as Saudi Arabia, addressing the lack of adequate information regarding farmers' pest management knowledge, perceptions, and practices is crucial $[27,28]$. Such information is vital in developing participatory IPM and as a basis for the adaptation of pest management technologies by local farming systems [29,30]. Furthermore, determining knowledge and adoption gaps is useful for developing educational programs to train farmers, setting the research agenda, testing research hypotheses, designing extension strategies, and evaluating the effectiveness of projects and development interventions [20,25,28,31]. In light of the scarce research available in the area of assessing farmers' knowledge and adoption of RPW management, the present study addresses this gap by achieving the following objectives: (i) clarifying farmers' knowledge of RPW symptoms, (ii) identifying farmers' adoption of management practices, and (iii) analyzing the nexus between farmers' adoption of RPW IPM and their knowledge of symptoms.

\section{Methodology}

\subsection{Description of the Study Area}

The study was conducted in Al-Umran district, Al-Ahsa Governorate (Figure 1). Al-Ahsa is located in the Eastern Region, which is located $328 \mathrm{~km}$ from the capital, Riyadh. The total area covers $379,000 \mathrm{~km}^{2}$, equivalent to $20 \%$ of the Kingdom of Saudi Arabia's total territory. The Empty Quarter Desert covers over three-quarters of the governorate, while its inhabited and active area represents about $20 \%$ of its total area. According to the official 2018 census, the population of Al-Ahsa Governorate was 1,063,000, representing about 36\% of the Eastern Region's population and 3\% of the overall population of Saudi Arabia [32]. The governorate is well-known for the Al-Ahsa Oasis, 
the largest oasis worldwide, which includes $92.3 \%$ of the population over approximately $860 \mathrm{~km}^{2}$. Moreover, the oasis includes more than 2.5 million palm trees [33]. The governorate's agroecology is comprised of $45.6 \%$ highlands (ranging from 100 to $400 \mathrm{~m}$ above sea level), $40 \%$ deserts (sand veins), and $12 \%$ coastal plains on the Arabian Gulf. Administratively, the governorate consists of 19 districts. Al-Umran District $\left(25.2524^{\circ} \mathrm{N}, 49.4313^{\circ} \mathrm{E}\right)$ is one of the most important cities in Al-Ahsa Governorate due to its geographical and economic importance and its high social and agricultural status among the governorate's regions and cities. The district is located in the eastern part of the Al-Ahsa Oasis and consists of 16 villages, with over 70,000 people occupying a total area of 2000 ha [34]. The annual mean temperature ranges between 20 and $38^{\circ} \mathrm{C}$ and the annual mean rainfall ranges between 90 and $180 \mathrm{~mm}$ [35]. The most important crops cultivated in the district include palm, rice, grapes, onions, tomatoes, okra, and eggplants [3]. The irrigation system in the district includes a Neogene groundwater aquifer and some free-flowing springs that flow naturally with water, and these springs are used to supply agricultural areas with water through a set of channels. The topography of the Al-Ahsa Oasis in the district is flat and rises $150 \mathrm{~m}$ above sea level [36,37].

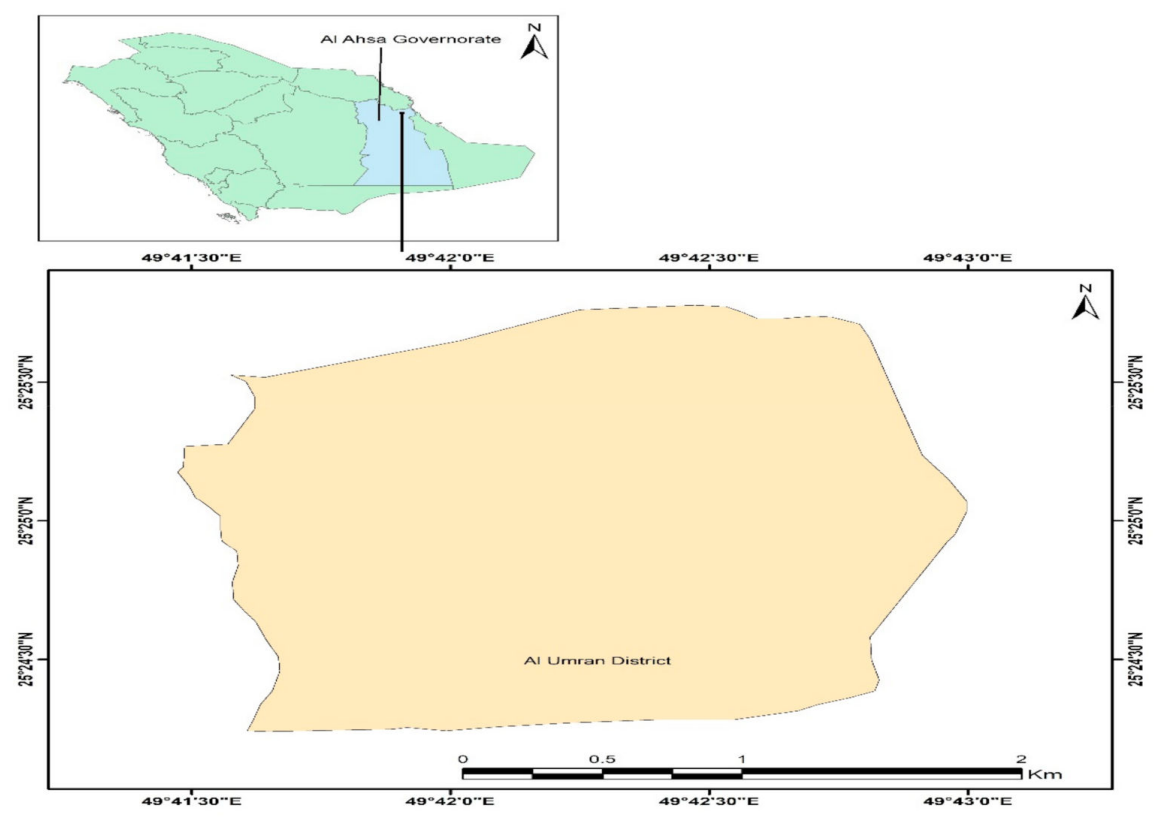

Figure 1. Map of the study area.

\subsection{Sampling Procedures}

A three-stage sampling procedure was implemented to select a representative sample of the farmers for the survey. In the first stage, Al-Umran district was purposely selected based on the production status of dates. In the second stage, five villages-namely, northern Al-Umran, southern Al-Umran, Al-Olaya, Abo Thor, and Al-Remila-were purposely selected based on the number of dates produced and the RPW problem. Finally, simple random sampling was employed and a total of 183 respondents were selected randomly from the selected villages using Yamane's [15] sample size determination formula, as indicated in the formula below:

$$
n=\frac{\mathrm{N}}{1+\mathrm{N}\left(e^{2}\right)}
$$

where $\mathrm{N}=$ the total number of farmers, $n=$ sample size, $e=$ accepted sampling error ( $7 \%$ in this study), and $\mathrm{N}=1863$. Therefore,

$$
n=\frac{1863}{1+1863\left(0.07^{2}\right)}=183
$$




\subsection{Survey Data Collection}

The survey was performed between November 2019 and February 2020. Personal interviews were conducted using semi-structured questionnaires (Supplementary Materials). Three extension workers were selected and trained to collect data from the respondents. The questionnaires focused on collecting information on socioeconomic characteristics, farmers' knowledge of RPW symptoms, and pest management practices. Farmers' knowledge of RPW symptoms was measured by asking an open-ended question-to describe the visual symptoms of RPW or the type of damage it causes on palm trees. Some respondents provided inaccurate answers (e.g., some symptoms related to other diseases or pests). These responses were excluded (after reviewing with plant protection experts at King Saud University). The present study adopted the following steps to analyze the open-ended question [38]: (1) data were organized into a template (Excel sheet); (2) responses were reviewed for accuracy of answers and incorrect responses' (3) response categories were identified (a set of replies that can be grouped because they are part of the same theme, even if they are worded differently); (4) the individual responses were matched with each category, and finally, categories were organized (the final categories of the symptoms presented in Figure 2).

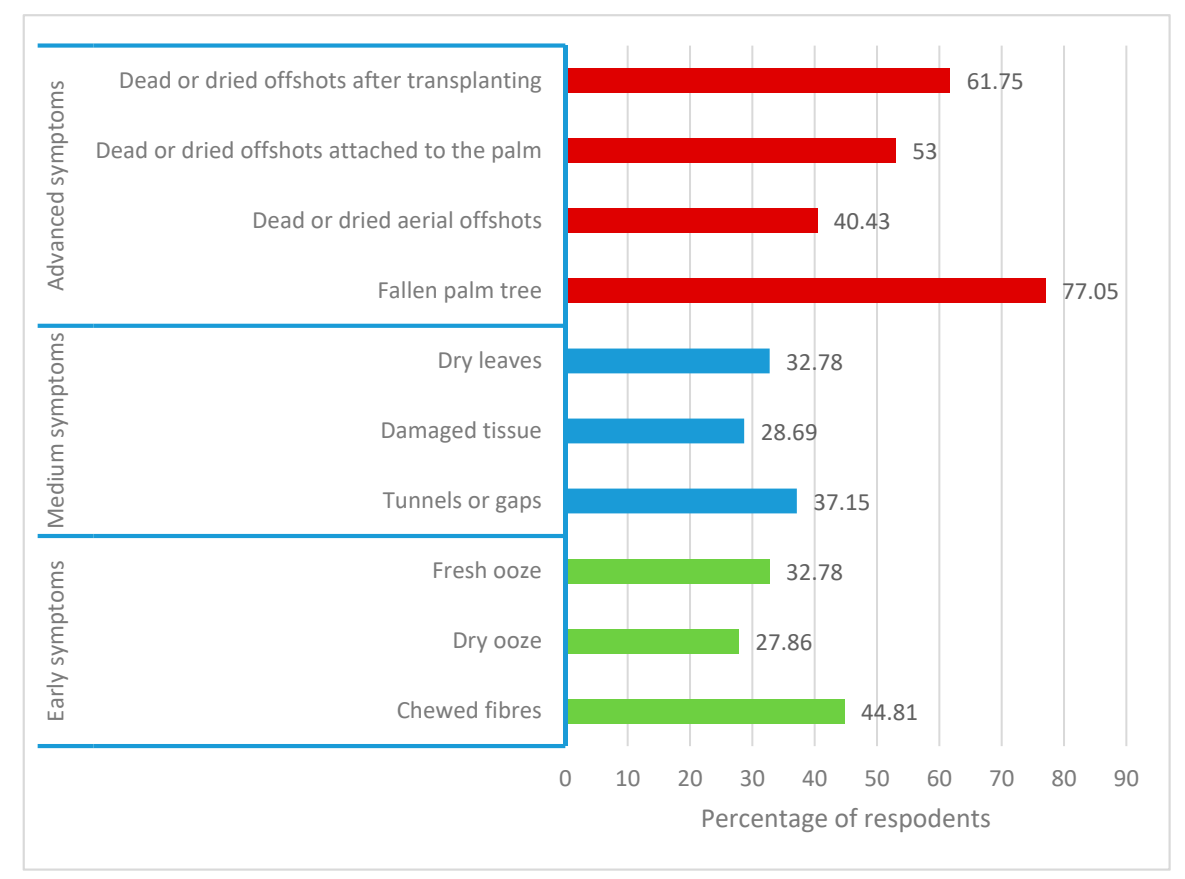

Figure 2. Farmers' knowledge of red palm weevil symptoms.

The farmers' knowledge level of symptoms was classified according to the number of symptoms identified as follows: low (fewer than four symptoms); moderate (between four and six symptoms); and high (more than six symptoms). The respondents were also asked to determine their IPM adoption level for RPW control on a five-point Likert scale ranging from $1=$ never to $5=$ always. The index of IPM practices comprised 23 practices, which were adopted and modified based on previous studies $[1,6,12,16,19,24,25]$. The total score for each respondent ranged between 23 and 115 . The overall adoption of all practices for each category was summed and converted into a percentage. Farmers' adoption was classified as high adoption if it was more than $75 \%$; moderate if it was between 50 and $75 \%$; and low if it was less than 50\%. The questionnaires were first prepared in English and then translated into Arabic. Five plant protection experts at King Saud University were selected to examine the questionnaires' content validity and suitability in the Saudi context. Furthermore, questionnaires were pre-tested on 10 farmers in the study area to assess the readability of questions and whether their intent is understood. 


\subsection{Data Analysis}

The survey data were analyzed using Statistical Package for Social Sciences (SPSS) software. Descriptive statistics (i.e., percentages, means, and standard deviations) were calculated. The Kruskal-Wallis test was performed to assess differences in farmers' adoptions regarding RPW symptoms. Dunn's test for multiple comparisons was used to determine which specific means are significant from the others [39]. Additionally, Kendall's tau-b was used to measure the strength and direction of the association between farmers' adoption of IPM and farmers' knowledge of RPW symptoms [40].

\section{Results}

\subsection{Socioeconomic Characteristics of Farmers}

The characteristics of the farmers are summarized in Table 1. The results indicate that the mean age of farmers was 55.08 years of age. Their mean level of education was 7.46 years. Moreover, the main occupation of more than one-third of the farmers (37.16\%) was farming. On average, the respondents had 25.34 years of farming experience and managed 6.87 ha of farmland. The mean number of palm trees on their farm was 551.19 trees. Furthermore, a small proportion of the respondents $(12.02 \%)$ cultivated more than one crop (i.e., in addition to palm) in the same physical space simultaneously. Regarding extension contact, the percentage of respondents who had regular contact with extension workers was $31.69 \%$. Around a quarter of the respondents $(27.86 \%)$ were members of the local agricultural association.

Table 1. Descriptive summary of farmers' characteristics.

\begin{tabular}{|c|c|c|}
\hline \multirow{2}{*}{ Farmers' Characteristics } & \multicolumn{2}{|c|}{ Number of Farmers $=183$} \\
\hline & Frequency & $\%$ \\
\hline \multicolumn{3}{|c|}{ Age $($ Min. $=23 ;$ Max. $=85 ;$ mean $=55.08 ; \mathrm{SD}=14.53)$} \\
\hline Less than 40 years & 27 & 14.75 \\
\hline $40-60$ years & 90 & 49.18 \\
\hline More than 60 years & 66 & 36.07 \\
\hline \multicolumn{3}{|c|}{ Education $($ Min. $=0 ;$ Max. $=16 ;$ mean $=7.64 ; \mathrm{SD}=3.08)$} \\
\hline Less than 7 years & 88 & 48.08 \\
\hline $7-12$ years & 66 & 36.07 \\
\hline More than 12 years & 29 & 15.85 \\
\hline \multicolumn{3}{|c|}{ Main occupation } \\
\hline Farmer & 68 & 37.16 \\
\hline Trader & 28 & 15.30 \\
\hline Craftsman & 11 & 6.01 \\
\hline Employee & 76 & 41.53 \\
\hline \multicolumn{3}{|c|}{ Farming experience $($ Min. $=3 ;$ Max. $=73 ;$ mean $=25.34 ; \mathrm{SD}=17.52)$} \\
\hline Less than 16 years & 63 & 34.4 \\
\hline $16-30$ years & 64 & 35.0 \\
\hline More than 30 years & 56 & 30.6 \\
\hline \multicolumn{3}{|c|}{ Farm size $($ Min. $=1 ;$ Max. $=19 ;$ mean $=6.87 ; \mathrm{SD}=4.05)$} \\
\hline Less than 6 hectares & 85 & 46.45 \\
\hline $6-10$ hectares & 60 & 32.79 \\
\hline More than 10 hectares & 38 & 20.76 \\
\hline \multicolumn{3}{|c|}{ Palm trees on the farm $($ Min. $=20 ;$ Max. $=2600 ;$ mean $=551.19 ; \mathrm{SD}=552.21)$} \\
\hline Less than 500 trees & 112 & 61.20 \\
\hline $500-1500$ trees & 60 & 32.79 \\
\hline More than 1500 trees & 11 & 6.01 \\
\hline \multicolumn{3}{|c|}{ Intercropping } \\
\hline Yes & 22 & 12.02 \\
\hline No & 161 & 87.98 \\
\hline \multicolumn{3}{|c|}{ Regular contact with extension workers } \\
\hline Yes & 58 & 31.69 \\
\hline No & 125 & 68.31 \\
\hline \multicolumn{3}{|c|}{ Membership in agricultural associations } \\
\hline Yes & 51 & 27.86 \\
\hline No & 132 & 72.14 \\
\hline
\end{tabular}




\subsection{Knowledge of RPW Symptoms}

Figure 2 presents the types of damage caused to palm trees by RPW. The findings demonstrate that RPW symptoms are highly varied in the perceptions of the respondents. The symptom of a fallen tree is the most well-known visual symptom perceived by respondents with a percentage of $77.05 \%$, followed by dead or dried offshoots after transplanting (61.75\%), and dead or dried offshoots attached to the palm (53\%). However, other symptoms were perceived less often by farmers. The results suggest that farmers are more aware of a high level of infestation or symptoms of damage than a medium or early infestation. In general, most farmers (45.4\%) had insufficient knowledge of RPW symptoms (Table 2), over a third (36.6\%) had moderate knowledge, and only $18 \%$ had a high level of knowledge.

Table 2. Farmers' knowledge level of symptoms.

\begin{tabular}{ccc}
\hline \multirow{2}{*}{ Knowledge Level } & \multicolumn{2}{c}{ Number of Farmers $=\mathbf{1 8 3}$} \\
\cline { 2 - 3 } & Frequency & Percentage \\
\hline Low (less than 4 symptoms) & 83 & 45.4 \\
Moderate (4-6 symptoms) & 67 & 36.6 \\
High (more than 6 symptoms) & 33 & 18 \\
\hline
\end{tabular}

\subsection{Adoption of IPM}

Farmers' adoption of IPM practices regarding RPW control is presented in Table 3. Overall, the farmers had a moderate level of adoption, with a percentage of $63.56 \%$ (Figure 3). Details of each IPM practice category are provided below.

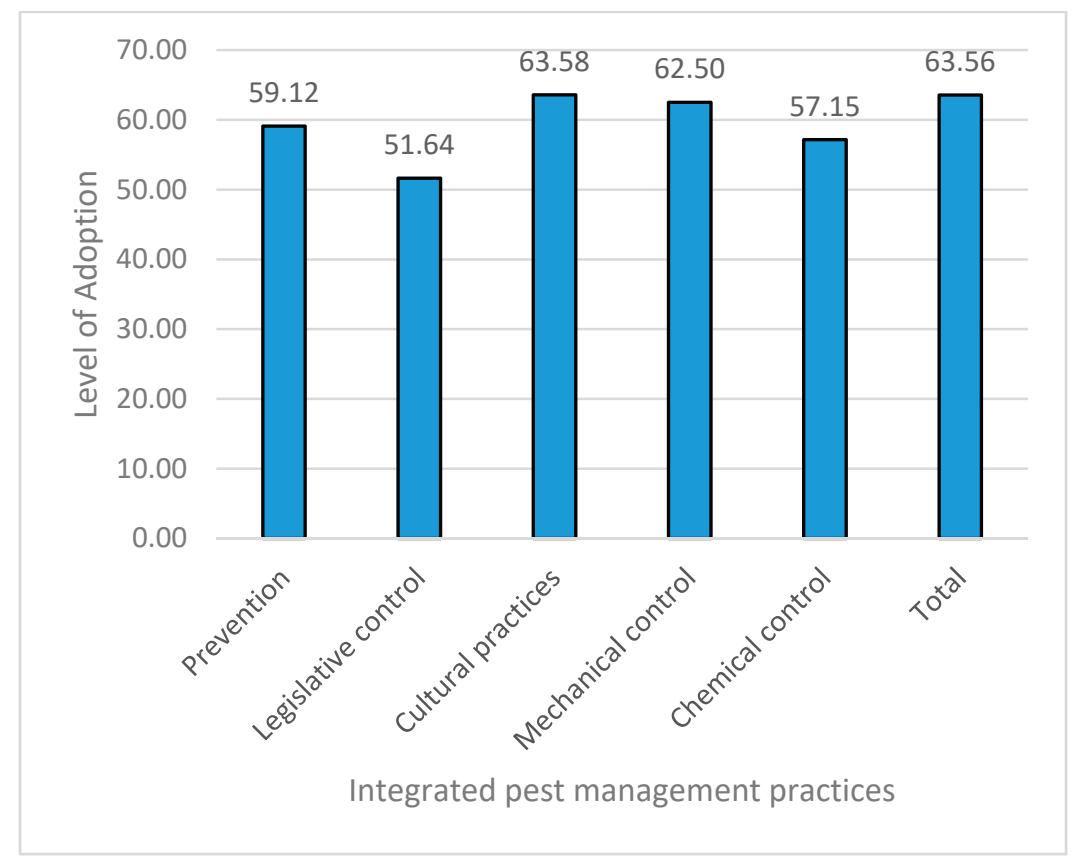

Figure 3. Overall adoption of integrated pest management categories for red palm weevil control. 
Table 3. Farmers' adoption of integrated pest management categories for red palm weevil control.

\begin{tabular}{|c|c|c|c|c|}
\hline \multirow{2}{*}{ Practice } & \multicolumn{2}{|c|}{ Adoption Level } & \multicolumn{2}{|c|}{ Rank } \\
\hline & Mean & SD & Within Group & Overall \\
\hline \multicolumn{5}{|l|}{ Prevention } \\
\hline P1-Checking trees at regular intervals to detect early infestation & 2.13 & 1.01 & 4 & 21 \\
\hline P2-Removing offshoots as a protective measure & 2.52 & 1.07 & 2 & 12 \\
\hline P3-Removing fonds by applying pruning in the winter & 2.54 & 1.17 & 1 & 11 \\
\hline P4-Using pheromone traps to detect early infestation & 2.12 & 1.09 & 5 & 22 \\
\hline $\begin{array}{l}\text { P5-Treating wounds resulted from removing frond bases and } \\
\text { offshoots by using contact pesticides }\end{array}$ & 2.32 & 1.03 & 3 & 16 \\
\hline \multicolumn{5}{|l|}{ Legislative control } \\
\hline $\begin{array}{l}\text { L1-Adhering to not transferring infested trees or offshoots to } \\
\text { non-infested areas }\end{array}$ & 3.28 & 0.79 & 2 & 2 \\
\hline $\begin{array}{l}\text { L2-Burning and burying the infested palm far away after cutting } \\
\text { it into small portions }\end{array}$ & 2.30 & 1.00 & 5 & 18 \\
\hline $\begin{array}{l}\text { L3-Adhering to not transferring infested palm waste to } \\
\text { other areas }\end{array}$ & 2.85 & 1.01 & 3 & 4 \\
\hline $\begin{array}{l}\text { L4-Surveying RPW-infested palms and informing authorities } \\
\text { when necessary }\end{array}$ & 2.60 & 1.18 & 4 & 10 \\
\hline $\begin{array}{l}\text { L5-Not allowing anyone to transfer infested offshoots from an } \\
\text { infested farm }\end{array}$ & 3.43 & 0.84 & 1 & 1 \\
\hline \multicolumn{5}{|l|}{ Cultural practices } \\
\hline $\begin{array}{l}\text { C1-Adhering to the time and depth specified for } \\
\text { planting offshoots }\end{array}$ & 2.75 & 1.18 & 1 & 5 \\
\hline C2-Applying moderate irrigation to reduce humidity on farms & 2.67 & 1.13 & 3 & 7 \\
\hline C3-Adhering to good plowing before planting & 2.65 & 0.94 & 4 & 8 \\
\hline C4-Maintaining the recommended distance between trees & 2.69 & 1.23 & 2 & 6 \\
\hline \multicolumn{5}{|l|}{ Mechanical control } \\
\hline $\begin{array}{l}\text { M1-Covering roots of small trees with soil to a height of } 20 \mathrm{~cm} \text { to } \\
\text { prevent insect attacks }\end{array}$ & 2.22 & 1.06 & 5 & 20 \\
\hline $\begin{array}{l}\text { M2-Removing weeds and dry trunks and disposing of them in } \\
\text { the recommended way }\end{array}$ & 2.63 & 1.10 & 2 & 9 \\
\hline M3-Eradicating infested palms & 3.18 & 0.95 & 1 & 3 \\
\hline $\begin{array}{l}\text { M4-Removing infested or dead trees and the pruning products } \\
\text { on neglected farms }\end{array}$ & 1.96 & 0.63 & 6 & 23 \\
\hline M5-Closing all openings on the trunks of palms & 2.51 & 1.28 & 3 & 13 \\
\hline M6-Scraping infested areas until healthy tissue is exposed & 2.29 & 1.03 & 4 & 19 \\
\hline \multicolumn{5}{|l|}{ Chemical control } \\
\hline $\mathrm{CH} 1-$ Spraying according to extension recommendations & 2.47 & 1.23 & 1 & 14 \\
\hline $\begin{array}{l}\mathrm{CH} 2 \text {-Spraying pesticides of a proper quantity and quality and } \\
\text { within the specified time frame }\end{array}$ & 2.42 & 1.18 & 2 & 15 \\
\hline $\mathrm{CH} 3-$ Dusting farms & 2.32 & 1.11 & 3 & 17 \\
\hline
\end{tabular}

\subsubsection{Prevention}

One of the main principles for the success of IPM programs is the application of preventive measures. Prevention focuses on removing conditions that attract pests, such as water, food, and shelter. The findings in Figure 2 show that the respondents had moderately adopted the preventive measures examined, with an overall mean of $59.12 \%$. The assessment of the two measures pertaining to RPW prevention (Table 3) shows that respondents considered "removing fonds by applying pruning in the winter" (mean $=2.54 ; \mathrm{SD}=1.17$ ) and "removing offshoots" (mean $=2.52 ; \mathrm{SD}=1.07$ ) as being of moderate adoption, while they adopted other preventive measures less often, which they indicated as being of low adoption.

\subsubsection{Legislative Control}

Pest control legislation is essential to prevent the introduction of foreign pests, diseases, and weeds. Applying legislative control measures is required to prevent the spread of already established pests 
and diseases within a country or a particular region. In our study, the overall mean for the adoption of legislative control measures was 51.64\%. However, the importance of burning infested palm far away after cutting it into small pieces to prevent the spread of RPW infestation had a very low level of adoption. Table 3 highlights that this practice was the least adopted by the respondents (mean $=2.30$; $\mathrm{SD}=1.00)$. By contrast, other legislative control measures were moderately adopted.

\subsubsection{Cultural Practices}

The adoption of cultural pest management practices is the practical application of the concept of avoidance. Cultural practices have long been recognized as an effective solution to avoid pest infestations at the farm level. The results shown in Figure 3 indicate that farmers had moderately adopted cultural measures for controlling RPW (63.58\%). The practices with the highest relevance rankings in order of adoption (Table 3) were adhering to the time and depth specified for planting offshoots (mean $=2.75 ; \mathrm{SD}=1.18)$, maintaining the recommended distance between trees (mean $=2.69$; $\mathrm{SD}=1.23)$, applying moderate irrigation to reduce humidity on the farm (mean $=2.67 ; \mathrm{SD}=1.13$ ), and adhering to good plowing before planting (mean $=2.65 ; \mathrm{SD}=0.94)$.

\subsubsection{Mechanical Control}

Table 3 presents the means and standard deviations of respondents' adoption of mechanical control practices. Mechanical pest control is a sustainable way to eliminate pests without harming the ecosystem. It includes weeding and adjusting the temperature to control pests and using physical means such as fences, barriers, or electronic wires. As shown in Figure 3, respondents had moderately adopted mechanical control practices, with a percentage of $62.50 \%$. For all six practices being assessed (Table 3 ), the adoption level ranged from low to moderate for all practices. The farmers rated "eradication of infested palms" as having the highest level of adoption (mean $=3.18 ; \mathrm{SD}=0.95$ ), while "removing palm trees on neglected farms" as having the lowest level of adoption (mean $=1.96 ; \mathrm{SD}=0.63$ ).

\subsubsection{Chemical Control}

In IPM, pesticides are selected and applied in a way that minimizes their potential harm to the environment, people, and non-targeted organisms. For more effective IPM programs, pesticides are used in combination with other approaches or used only when needed. In our study, the overall mean for farmers' adoption of chemical control practices was 57.15\% (Figure 3), indicating that farmers had moderately adopted these practices in their farming context. Obviously, the assessment of the three statements pertaining to chemical control methods (Table 3) demonstrates that respondents considered the adoption of chemical control practices (i.e., spraying according to extension recommendations, spraying pesticides in quantities and qualities within the specified time, and dusting farms) as being of a low level (mean $<2.5)$.

In general, Table 4 shows the RPW IPM adoption patterns among palm growers in Saudi Arabia based on the overall mean responses obtained during the survey. The results indicate that $45.36 \%$ of the respondents were in the "moderate adoption" category, $41.53 \%$ were in the "low adoption" category, and the remaining $13.11 \%$ were in the "high adoption" category.

Table 4. Distribution of farmers according to their adoption level of integrated pest management categories for red palm weevil control.

\begin{tabular}{ccc}
\hline \multirow{2}{*}{ Adoption Level } & \multicolumn{2}{c}{ Number of Farmers $=\mathbf{1 8 3}$} \\
\cline { 2 - 3 } & Frequency & Percentage (\%) \\
\hline Low (fewer than $50 \%)$ & 76 & 41.53 \\
Moderate $(50-75 \%)$ & 83 & 45.36 \\
High (more than $75 \%)$ & 24 & 13.11 \\
\hline
\end{tabular}




\subsection{Nexus between Farmers' Adoption of IPM and Knowledge of RPW Symptoms}

To better assess the nexus between farmers' adoption and knowledge of symptoms, we classified the level of adoption based on the various levels of knowledge in each category of RPW IPM, as illustrated in Figure 4. The findings reveal that farmers in the "high knowledge" category had higher adoption rates in all RPW IPM categories than farmers in the moderate and the low level of knowledge categories. The level of adoption in the "high knowledge" category was moderate in all RPW IPM categories and ranged between the minimum (63.03\%) for the "prevention" category and the maximum (69.69\%) for the "legislative control" category. Conversely, the level of adoption in the "low knowledge" category was low in all RPW IPM categories and ranged between the minimum (26.20\%) for the "chemical control" category and the maximum (45.90\%) for the "legislative control" category. In total, overall adoption was in the same pattern of the IPM categories, in which the "high knowledge" category ranked first regarding the level of adoption, with a percentage of $55.17 \%$, followed by the "moderate knowledge" category (59.11\%) and the "low knowledge" category $(36.49 \%)$.

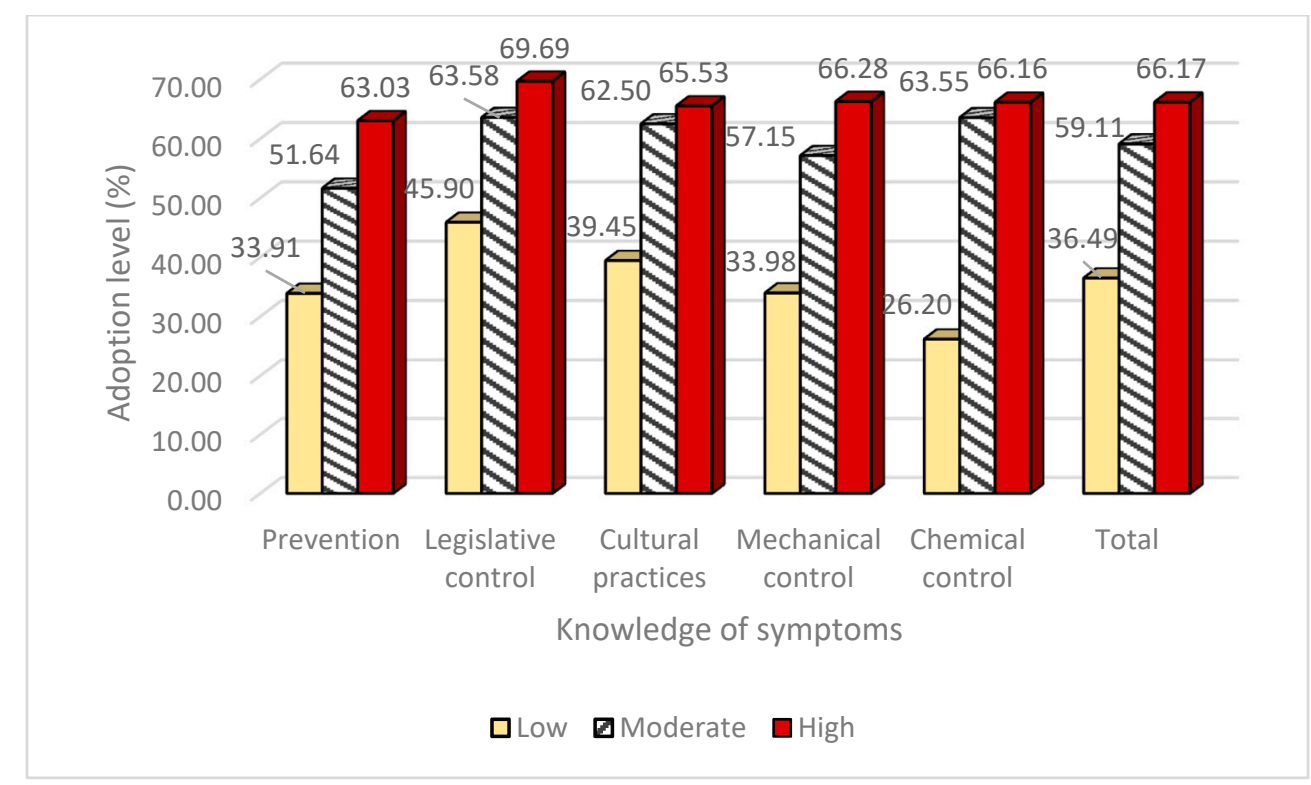

Figure 4. Farmers' adoption level of integrated pest management categories according to farmers' knowledge of symptoms.

The results of the Kruskal-Wallis analysis in Table 5 reveal that highly significant differences exist between all adoption categories regarding farmers' knowledge of symptoms in the various IPM practices, examined at $p<0.01$. According to the results of Dunn's test, the mean value of the "high adoption" category significantly differed from the group means for the "low adoption" category.

The foregoing analysis demonstrates that farmers differed in their adoption based on their level of knowledge of RPW symptoms in each practice. To further understand the strength of the association between adoption and knowledge, Kendall's tau-b was applied (Table 6). The findings indicate a significant positive correlation between farmers' level of IPM and their knowledge of RPW symptoms at $p<0.01$. The value of Kendall's tau-b (0.81) reflects the strength of the association between the two variables. This indicates that the respondents with a higher level of knowledge of RPW symptoms scored higher on the items related to IPM adoption. 
Table 5. Differences in farmers' adoption of integrated pest management regarding farmers' knowledge of symptoms.

\begin{tabular}{|c|c|c|c|c|c|c|c|c|c|c|c|c|}
\hline \multirow{3}{*}{ Practice } & \multicolumn{6}{|c|}{ Knowledge of Symptoms } & \multirow{2}{*}{\multicolumn{2}{|c|}{ Kruskal-Wallis Test }} & \multirow{2}{*}{\multicolumn{4}{|c|}{ Dunn's Test }} \\
\hline & \multicolumn{2}{|c|}{ Low } & \multicolumn{2}{|c|}{ Moderate } & \multicolumn{2}{|c|}{ High } & & & & & & \\
\hline & Mean & SD & Mean & SD & Mean & SD & Chi-Square & $p$-value & Mean & ifference & Std. Error & $p$-Value \\
\hline P1 & 1.65 & 0.67 & 2.12 & 0.87 & 3.37 & 0.96 & $61.17^{* *}$ & 0.00 & $\begin{array}{l}\text { L-M } \\
\text { L-H } \\
\text { M-H }\end{array}$ & $\begin{array}{l}-25.49^{* *} \\
-78.08^{* *} \\
-52.58^{* *}\end{array}$ & $\begin{array}{c}7.98 \\
9.99 \\
10.33 \\
\end{array}$ & $\begin{array}{l}0.00 \\
0.00 \\
0.00\end{array}$ \\
\hline P2 & 2.01 & 0.99 & 2.70 & 0.88 & 3.40 & 0.95 & 40.99 ** & 0.00 & $\begin{array}{l}\text { L-M } \\
\text { L-H } \\
\text { M-H } \\
\end{array}$ & $\begin{array}{c}-33.55^{* *} \\
-62.62^{* *} \\
29.06^{* *}\end{array}$ & $\begin{array}{c}8.23 \\
10.32 \\
10.66 \\
\end{array}$ & $\begin{array}{l}0.00 \\
0.00 \\
0.00\end{array}$ \\
\hline P3 & 1.71 & 0.79 & 3.00 & 0.92 & 3.67 & 0.98 & $82.48^{* *}$ & 0.00 & $\begin{array}{l}\text { L-M } \\
\text { L-H } \\
\text { M-H }\end{array}$ & $\begin{array}{l}-57.57 \text { ** } \\
-82.00 * * \\
-24.42 *\end{array}$ & $\begin{array}{c}8.25 \\
10.34 \\
10.69 \\
\end{array}$ & $\begin{array}{l}0.00 \\
0.00 \\
0.02\end{array}$ \\
\hline P4 & 1.28 & 0.27 & 2.44 & 0.76 & 3.59 & 10.02 & $124.19^{* *}$ & 0.00 & $\begin{array}{l}\text { L-M } \\
\text { L-H } \\
\text { M-H }\end{array}$ & $\begin{array}{l}-63.18^{* *} \\
-99.87^{* *} \\
-36.68^{* *}\end{array}$ & $\begin{array}{c}7.89 \\
9.89 \\
10.22\end{array}$ & $\begin{array}{l}0.00 \\
0.00 \\
0.00\end{array}$ \\
\hline P5 & 1.80 & 0.89 & 2.68 & 0.84 & 2.91 & 10.06 & $44.38^{* *}$ & 0.00 & $\begin{array}{l}\text { L-M } \\
\text { L-H } \\
\text { M-H }\end{array}$ & $\begin{array}{c}-46.54^{* *} \\
-53.38^{* *} \\
-6.83\end{array}$ & \begin{tabular}{|c|}
8.14 \\
10.2 \\
10.54 \\
\end{tabular} & $\begin{array}{l}0.00 \\
0.00 \\
0.51\end{array}$ \\
\hline L1 & 2.86 & 0.66 & 3.48 & 0.59 & 3.93 & 0.83 & 49.03 ** & 0.00 & $\begin{array}{l}\text { L-M } \\
\text { L-H } \\
\text { M-H }\end{array}$ & $\begin{array}{l}-39.58^{* *} \\
-61.40^{* *} \\
-21.81^{*}\end{array}$ & $\begin{array}{c}7.77 \\
9.73 \\
10.06\end{array}$ & $\begin{array}{l}0.00 \\
0.00 \\
0.03\end{array}$ \\
\hline L2 & 1.50 & 0.50 & 2.79 & 0.72 & 3.29 & 0.92 & $107.90 * *$ & 0.00 & $\begin{array}{c}\text { L-M } \\
\text { L-H } \\
\text { M-H }\end{array}$ & $\begin{array}{c}-69.36^{* *} \\
-86.79^{* *} \\
-17.42 \\
\end{array}$ & $\begin{array}{c}8.10 \\
10.15 \\
10.49 \\
\end{array}$ & $\begin{array}{l}0.00 \\
0.00 \\
0.09 \\
\end{array}$ \\
\hline L3 & 2.28 & 0.97 & 3.20 & 0.79 & 3.56 & 0.70 & $49.14^{* *}$ & 0.00 & $\begin{array}{l}\text { L-M } \\
\text { L-H } \\
\text { M-H }\end{array}$ & $\begin{array}{c}-44.81^{* *} \\
-60.57 * * \\
-15.75\end{array}$ & \begin{tabular}{c|}
8.08 \\
10.12 \\
10.46 \\
\end{tabular} & $\begin{array}{l}0.00 \\
0.00 \\
0.13\end{array}$ \\
\hline L4 & 1.71 & 0.88 & 2.98 & 0.68 & 4.09 & 0.64 & $103.94 * *$ & 0.00 & $\begin{array}{l}\text { L-M } \\
\text { L-H } \\
\text { M-H }\end{array}$ & $\begin{array}{l}-56.24^{* *} \\
-98.74^{* *} \\
-42.22^{* *}\end{array}$ & $\begin{array}{c}8.25 \\
10.34 \\
10.69\end{array}$ & $\begin{array}{l}0.00 \\
0.00 \\
0.00\end{array}$ \\
\hline L5 & 3.10 & 0.78 & 3.50 & 0.69 & 4.12 & 0.79 & $35.75^{* *}$ & 0.00 & $\begin{array}{c}\text { L-M } \\
\text { L-H } \\
\text { M-H }\end{array}$ & $\begin{array}{l}-22.86^{* *} \\
-55.57^{* *} \\
-32.71^{* *}\end{array}$ & $\begin{array}{l}7.52 \\
9.42 \\
9.74 \\
\end{array}$ & $\begin{array}{l}0.00 \\
0.00 \\
0.00\end{array}$ \\
\hline $\mathrm{C} 1$ & 1.91 & 0.98 & 3.30 & 0.77 & 3.78 & 0.85 & 79.38 ** & 0.00 & $\begin{array}{c}\text { L-M } \\
\text { L-H } \\
\text { M-H }\end{array}$ & $\begin{array}{c}-58.56^{* *} \\
-77.39^{* *} \\
-18.83\end{array}$ & $\begin{array}{c}8.20 \\
10.28 \\
10.62 \\
\end{array}$ & $\begin{array}{l}0.00 \\
0.00 \\
0.07 \\
\end{array}$ \\
\hline $\mathrm{C} 2$ & 2.00 & 0.89 & 3.04 & 0.90 & 3.63 & 10.09 & $58.05^{* *}$ & 0.00 & $\begin{array}{c}\text { L-M } \\
\text { L-H } \\
\text { M-H }\end{array}$ & $\begin{array}{c}-48.19^{* *} \\
-69.21^{* *} \\
-21.02 \\
\end{array}$ & $\begin{array}{c}8.28 \\
10.37 \\
10.72 \\
\end{array}$ & $\begin{array}{l}0.00 \\
0.00 \\
0.15\end{array}$ \\
\hline C3 & 2.25 & 0.96 & 3.02 & 0.84 & 2.91 & 0.67 & 26.24 ** & 0.00 & $\begin{array}{c}\text { L-M } \\
\text { L-H } \\
\text { M-H }\end{array}$ & $\begin{array}{c}-31.60 \text { ** } \\
-39.84^{* *} \\
8.24\end{array}$ & $\begin{array}{c}10.16 \\
8.11 \\
10.50 \\
\end{array}$ & $\begin{array}{l}0.00 \\
0.00 \\
0.43 \\
\end{array}$ \\
\hline $\mathrm{C} 4$ & 1.71 & 0.88 & 3.22 & 0.65 & 4.05 & 0.88 & $104.26^{* *}$ & 0.00 & $\begin{array}{c}\text { L-M } \\
\text { L-H } \\
\text { M-H }\end{array}$ & $\begin{array}{l}-63.83^{* *} \\
-93.34^{* *} \\
-29.50^{* *}\end{array}$ & $\begin{array}{c}8.27 \\
10.37 \\
10.71 \\
\end{array}$ & $\begin{array}{l}0.00 \\
0.00 \\
0.00 \\
\end{array}$ \\
\hline M1 & 1.28 & 0.19 & 2.48 & 0.15 & 4.09 & 0.56 & $174.38^{* *}$ & 0.00 & $\begin{array}{l}\text { L-M } \\
\text { L-H } \\
\text { M-H }\end{array}$ & $\begin{array}{l}-72.07^{* *} \\
-123.69^{* *} \\
-51.56^{* *}\end{array}$ & $\begin{array}{c}8.05 \\
10.08 \\
10.42\end{array}$ & $\begin{array}{l}0.00 \\
0.00 \\
0.00\end{array}$ \\
\hline M2 & 1.97 & 0.95 & 2.96 & 0.80 & 3.63 & 0.90 & 61.53 ** & 0.00 & $\begin{array}{c}\text { L-M } \\
\text { L-H } \\
\text { M-H }\end{array}$ & $\begin{array}{l}-46.64^{\text {** }} \\
-73.49^{\text {** }} \\
-26.85^{\text {** }}\end{array}$ & $\begin{array}{c}8.26 \\
10.35 \\
10.69\end{array}$ & $\begin{array}{l}0.00 \\
0.00 \\
0.01\end{array}$ \\
\hline M3 & 2.37 & 0.60 & 3.65 & 0.39 & 4.28 & 0.70 & $130.05^{* *}$ & 0.00 & $\begin{array}{c}\text { L-M } \\
\text { L-H } \\
\text { M-H } \\
\end{array}$ & $\begin{array}{l}-71.94^{* *} \\
-98.23^{* *} \\
-26.29^{* *}\end{array}$ & \begin{tabular}{c|}
8.01 \\
10.04 \\
10.38 \\
\end{tabular} & $\begin{array}{l}0.00 \\
0.00 \\
0.01 \\
\end{array}$ \\
\hline M4 & 1.55 & 0.53 & 2.25 & 0.49 & 2.38 & 0.48 & 64.39 ** & 0.00 & $\begin{array}{l}\text { L-M } \\
\text { L-H } \\
\text { M-H }\end{array}$ & $\begin{array}{c}-51.41^{* *} \\
-59.60^{* *} \\
-8.18\end{array}$ & $\begin{array}{l}7.50 \\
9.39 \\
9.71\end{array}$ & $\begin{array}{l}0.00 \\
0.00 \\
0.39\end{array}$ \\
\hline M5 & 1.26 & 0.13 & 3.24 & 0.69 & 4.16 & 0.59 & $161.87^{* *}$ & 0.00 & $\begin{array}{c}\text { L-M } \\
\text { L-H } \\
\text { M-H }\end{array}$ & $\begin{array}{c}-81.34^{* *} \\
-111.15^{* *} \\
-29.81\end{array}$ & $\begin{array}{c}8.13 \\
10.18 \\
10.52 \\
\end{array}$ & $\begin{array}{l}0.00 \\
0.00 \\
0.00\end{array}$ \\
\hline M6 & 1.74 & 0.91 & 2.61 & 0.86 & 3.03 & 0.93 & $50.21 * *$ & 0.00 & $\begin{array}{c}\text { L-M } \\
\text { L-H } \\
\text { M-H }\end{array}$ & $\begin{array}{c}-45.03^{* *} \\
-62.29^{* *} \\
-17.26 \\
\end{array}$ & $\begin{array}{c}8.13 \\
10.19 \\
10.53 \\
\end{array}$ & $\begin{array}{c}0.00 \\
0.00 \\
0.1 \\
\end{array}$ \\
\hline $\mathrm{CH} 1$ & 1.28 & 0.27 & 3.26 & 0.61 & 3.86 & 0.84 & $154.32 * *$ & 0.00 & $\begin{array}{c}\text { L-M } \\
\text { L-H } \\
\text { M-H }\end{array}$ & $\begin{array}{c}-83.90^{* *} \\
-102.80^{* *} \\
-18.89\end{array}$ & $\begin{array}{c}8.11 \\
10.16 \\
10.50\end{array}$ & $\begin{array}{l}0.00 \\
0.00 \\
0.07\end{array}$ \\
\hline $\mathrm{CH} 2$ & 1.32 & 0.40 & 3.22 & 0.65 & 3.56 & 0.89 & $143.85^{* *}$ & 0.00 & $\begin{array}{c}\text { L-M } \\
\text { L-H } \\
\text { M-H }\end{array}$ & $\begin{array}{c}-84.84^{* *} \\
-94.79^{* *} \\
-9.95\end{array}$ & $\begin{array}{c}8.15 \\
10.21 \\
10.55 \\
\end{array}$ & $\begin{array}{l}0.00 \\
0.00 \\
0.34 \\
\end{array}$ \\
\hline $\mathrm{CH} 3$ & 1.32 & 0.35 & 3.07 & 0.66 & 3.33 & 0.97 & $143.02 * *$ & 0.00 & $\begin{array}{l}\text { L-M } \\
\text { L-H } \\
\text { M-H }\end{array}$ & $\begin{array}{c}-86.20 * * \\
-91.92 * * \\
-5.72\end{array}$ & $\begin{array}{c}8.15 \\
10.22 \\
10.56\end{array}$ & $\begin{array}{l}0.00 \\
0.00 \\
0.58\end{array}$ \\
\hline
\end{tabular}


Table 6. Association between farmers' adoption of integrated pest management and their knowledge of symptoms.

\begin{tabular}{|c|c|c|c|c|c|c|c|c|c|c|}
\hline \multirow{3}{*}{$\begin{array}{l}\text { Knowledge } \\
\text { Level of } \\
\text { Symptoms }\end{array}$} & \multicolumn{6}{|c|}{ Adoption Level } & \multirow{2}{*}{\multicolumn{2}{|c|}{ Total }} & \multirow{3}{*}{$\begin{array}{l}\text { Kendall's } \\
\text { Correlation } \\
\text { Coefficient }\end{array}$} & \multirow{3}{*}{ p-Value } \\
\hline & \multicolumn{2}{|c|}{ Low } & \multicolumn{2}{|c|}{ Moderate } & \multicolumn{2}{|c|}{ High } & & & & \\
\hline & Freq. & $\%$ & Freq. & $\%$ & Freq. & $\%$ & Freq. & $\%$ & & \\
\hline Low & 73 & 96.1 & 10 & 12.0 & 0 & 0.0 & 83 & 45.5 & \multirow{4}{*}{$0.81^{* *}$} & \multirow{4}{*}{0.00} \\
\hline Moderate & 3 & 3.9 & 58 & 69.9 & 6 & 25 & 67 & 36.6 & & \\
\hline High & 0 & 0.0 & 15 & 18.1 & 18 & 75.0 & 33 & 18.0 & & \\
\hline Total & 76 & 100 & 83 & 100 & 24 & 100 & 183 & 100 & & \\
\hline
\end{tabular}

\section{Discussion}

Developing the best management practices for RPW eradication is always a concern for researchers and farmers in various countries to increase productivity and ensure sustainable livelihoods. The adverse impacts of RPWs at the micro and macro levels have received much attention in the literature. The present study demonstrates that early detection and knowledge of symptoms and applying IPM are crucial for effective control and eradication. While farmers' actual adoption rates for the RPW IPM have not previously been documented in Saudi Arabia, these findings are consistent with the country's 2030 vision for developing an active policy for developing the palm sector by reducing RPW risks [41].

Visual inspection for damage is the first step of an overall IPM strategy against RPW. Our findings show that the knowledge level of most farmers surveyed in this study regarding visual symptoms of RPW is low. This means that farmers face difficulties in visually detecting infestation during the various stages. This might be because farmers lack sufficient understanding of how RPWs cause damage and knowledge of their life cycle. In fact, the early detection of infestation and damage is difficult since palm trees do not show visual evidence of infection until the palm reaches a medium or an advanced stage of infestation [16,42]. According to Muriithi et al. [43], one of the main principles of IPM is prevention by monitoring plants regularly and making accurate diagnoses by observing symptoms and learning the lifecycle and damage potential to facilitate decision-making about the best time to take action. Our results reveal that farmers rarely check palm trees at regular intervals to detect early infestation in this context. In other words, farmers do not keep in mind that prevention is better than cure. As the Food and Agriculture Organization (FAO) [25] argued, detecting RPW infestation in its early stages can be achieved by conducting training programs for farmers to enhance their knowledge and skills on early detection and inspection methods. Furthermore, developing a reliable, easy-to-use, and cost-effective RPW detection device is an effective solution for reducing the gap in early detection [44]. In this regard, the literature provides some successful examples of early detection techniques in terms of efficiency, ease of use, and cost-effectiveness, such as biological and physiological indicators, thermal imaging, chemical signatures, acoustics, laser-induced remote sensing, breakdown spectroscopy, and near-infrared spectroscopy [9,44-49]. Additionally, the FAO established a global RPW management platform that includes a mobile app tool for collecting and transmitting data on palm inspection [16]. However, maximizing the benefits from early detection techniques requires overcoming challenges such as improving farmers' involvement in detecting RPW-infested palms, developing a uniform protocol for visual inspection, surveillance and monitoring, and using a geographic information system (GIS) platform to register the detection of infested palms $[16,24,25]$.

Calculation of adoption rates enabled an assessment of the extent to which respondents were practicing RPW IPM. Practically, in the present study, a medium variation in the farmers' adoption of RPW IPM was observed. Specifically, farmers' adoption had fallen to a low and moderate level for all practices under investigation. Given these adoption levels among Saudi Arabian palm farmers, it is more relevant to discuss the varying levels of IPM use rather than how to increase adoption in general. For the preventive category, however, despite the importance of directing efforts toward applying preventive measures for RPW control and eradication [50], the rates of farmers' adoption 
did not reach the high level. These rates could increase the percentages of RPW infestation as a result of non-adoption. This might be attributed to the lack of famers' knowledge about the importance of preventive measures as the main component of the general IPM principles due to irregular contact with the local extension, as illustrated in Table 1 . The results indicate that farmers have good knowledge about not transferring infested trees or offshoots to non-infested areas and not allowing anyone to transfer infested offshoots from an infested farm as legislative measures. This might be due to the application of inspection points and agricultural quarantines between date palm production areas and farmers' perception of legal penalties in case of violations. Other legislative measures, such as burying the infested palm far away after cutting it into small pieces, surveying RPW-infested palms, and not transferring the infested palm waste to another area, did not attract the same attention among farmers. This might be attributed to the fact that to perform these operations, many workers are required, and most farmers are preoccupied with producing dates without cleaning the farm and disposing or recycling waste.

The findings also highlight that the level of adopting cultural practices was above average. This might be due to those farmers performing these practices once at the beginning of the season or when establishing their palm farm. Some mechanical control practices are rarely implemented by farmers, such as covering the roots of small trees with soil to a height of $20 \mathrm{~cm}$ and scraping infested areas until the healthy tissue is exposed. This might be due to the fact that farmers do not have sufficient knowledge about the importance of these practices in preventing RPW attacks. In the same sense, however, the importance of removing of infested or dead trees and pruning products on neglected farms for RPW control and eradication was ranked last among other mechanical control measures. This might be due to the fact that farmers cannot do anything on abandoned farms where they are not the owners. Other possible explanations for this result can be due to farmers' unwillingness to pay additional costs without any economic benefit and the absence of collective action by farmers' associations in organizing efforts to manage infested trees on neglected farms. Regarding chemical control, IPM reduces pesticides by the application of a range of environmentally compatible methods. The adoption level of chemical control recommendations among farmers was below average. This might be due to the large number of pesticide companies promoting their products and persuading farmers to use them without being informed of the implications. Furthermore, the lack of effective natural/biological insecticides for RPW control is another factor contributing to the extensive use of pesticides [41]. These findings are in line with the findings of Abd Rabou and Radwan [51], who found that farmers in the Gaza Strip frequently used preventive and curative RPW insecticides.

An interrelationship between farmers' adoption of RPW IPM and their knowledge of symptoms was observed. This means that farmers with a higher perception of visual symptoms of RPW exhibited higher adoption rates. In this regard, Donatelli et al. [52] clarified that knowledge of pests' signs and symptoms denotes awareness and perception of the damage resulting from infection. Correctly diagnosing symptoms is the first step in identifying possible solutions to a plant health problem and supports IPM decisions. Consequently, some management practices should be implemented by the government and farmers, including developing a protocol for visual inspection of RPW infestation; establishing a quick, reliable, cost-effective, and easily applicable early detection device or technique for RPW infestation; and conducting a risk assessment of the area using both visual observation and pheromone traps [25]. This result is aligned with other studies $[20,30,53,54]$ that have reported a positive relationship between knowledge of symptoms and IPM adoption for various pests.

\section{Conclusions}

To the best of our knowledge, this study is one of the first to examine farmers' knowledge and IPM adoption behavior regarding RPW control. It was found that Saudi palm farmers require support to visually diagnose the symptoms of RPW. The level of farmers' adoption of IPM categories (i.e., preventive, legislative, cultural, mechanical, and chemical) ranged between low and medium rates for all practices. Our results confirmed that RPW eradication requires collaboration between all 
stakeholders to control infestation sources, specifically in removing infested or dead trees and pruning products from neglected farms. However, an in-depth examination of the relationships between knowledge of RPW symptoms and IPM adoption demonstrates an interesting interplay between the two components. The evidence indicates that farmers with more experience in diagnosing RPW symptoms were more likely to adopt IPM. This research provides useful implications for policymakers. Developing an easy-to-use management platform-e.g., a mobile app tool that includes various RPW symptoms to bridge the knowledge gap identified in this study-is crucial. Furthermore, training farmers is also required. Training programs should aim to raise awareness among farmers about the significance of the RPW issue and the importance of removal and disposal of infested palms. These programs should also focus on developing farmers' skills to use early detection devices or techniques for RPW infestation; implement good agronomic practices that limit RPW attack; develop a follow-up plan for preventive measures; conduct a risk assessment of the farm, adopting both visual observation and pheromone traps; and use preventive insecticide treatments based on trap capture data and infestation foci. To increase IPM adoption of RPW among farmers, facilitating knowledge-sharing on the consequences of IPM compliance is important. This can be achieved by organizing extension approaches such as farmer field schools. Future research analyzing the influence of social and economic aspects on IPM adoption at various infestation levels would be interesting. Such a focus could further clarify the factors influencing farmers' IPM adoption for RPW control and eradication.

Supplementary Materials: The following are available online at http://www.mdpi.com/2071-1050/12/22/9647/s1.

Author Contributions: Instrument design and writing, H.S.K.; validation, data analysis, and methodology, B.A.A.; conceptualization and data curation, A.A.; review and suggestions, F.O.A. All authors have read and agreed to the published version of the manuscript.

Funding: This research was funded by the Deanship of Scientific Research, King Saud University, Saudi Arabia, through the Research Group No. RGP-1440-006.

Acknowledgments: The authors are grateful to the Deanship of Scientific Research and RSSU at the King Saud University for their technical support. We are also grateful to Maged Elkahky, Agricultural officer, Transboundary Plant Pests Team, FAO, for his assistance in reviewing the index of RPW IPM.

Conflicts of Interest: The authors declare no conflict of interest.

\section{References}

1. Sallam, A.; El-Shafie, H.; Al-Abdan, S. Influence of farming practices on infestation by red palm weevil rhynchophorus ferrugineus (olivier) in date palm: A case study. Int. Res. J. Agric. Sci. Soil Sci. 2012, 2, 370-376.

2. FAOSTAT. Crop Statistics; FAO: Rome, Italy, 2019.

3. Ministry of Environment, Water and Agriculture (MEWA). Annual Statistical Book; Ministry of Environment, Water and Agriculture (MEWA): Riyadh, Saudi Arabia, 2019.

4. Nadeem, M.; Qureshi, T.M.; Ugulu, I.; Riaz, M.N.; An, Q.; Khan, Z.I.; Ahmad, K.; Ashfaq, A.; Bashir, H.; Dogan, Y. Mineral, vitamin and phenolic contents and sugar profiles of some prominent date palm (phoenix dactylifera) varieties of pakistan. Pak. J. Bot. 2019, 51, 171-178. [CrossRef]

5. Yasin, B.R.; El-Fawal, H.A.; Mousa, S.A. Date (phoenix dactylifera) polyphenolics and other bioactive compounds: A traditional islamic remedy's potential in prevention of cell damage, cancer therapeutics and beyond. Int. J. Mol. Sci. 2015, 16, 30075-30090. [CrossRef] [PubMed]

6. Al-Dosary, N.M.; Al-Dobai, S.; Faleiro, J.R. Review on the management of red palm weevil rhynchophorus ferrugineus olivier in date palm Phoenix dactylifera L. Emir. J. Food Agric. 2016, 34-44. [CrossRef]

7. Aleid, S.M.; Al-Khayri, J.M.; Al-Bahrany, A.M. Date Palm Status and Perspective in Saudi Arabia. In Date Palm Genetic Resources and Utilization; Springer: Berlin/Heidelberg, Germany, 2015; pp. 49-95.

8. Abdel-Raheem, M.; ALghamdi, H.A.; Reyad, N.F. Nano essential oils against the red palm weevil, rhynchophorus ferrugineus olivier (coleoptera: Curculionidae). Entomol. Res. 2020, 50, 215-220. [CrossRef] 
9. Koubaa, A.; Abdulrahman, A.; Bassel, S.; Abdullatif, H.; Mohanned, A.; Abdulrahman, S.; Hesham, A.; Adel, A.; Mohamed, A. Smart palm: An iot framework for red palm weevil early detection. Agronomy 2020, 10, 987. [CrossRef]

10. AlJabr, A.M.; Hussain, A.; Rizwan-ul-Haq, M.; Al-Ayedh, H. Toxicity of plant secondary metabolites modulating detoxification genes expression for natural red palm weevil pesticide development. Molecules 2017, 22, 169. [CrossRef]

11. Haq, I.U.; Shams, S.; Khan, S.; Khan, A.; Hameed, A. A novel report on morphological study of red palm weevil (rhynchophorus ferrugineus) from district bannu kpk, pakistan. Cogent Food Agric. 2018, 4, 1425117.

12. Dembilio, Ó.; Jaques, J.A. Biology and Management of Red Palm Weevil. In Sustainable Pest Management in Date Palm: Current Status and Emerging Challenges; Springer: Berlin/Heidelberg, Germany, 2015; pp. 13-36.

13. Giblin-Davis, R.M.; Faleiro, J.R.; Jacas, J.A.; Peña, J.E.; Vidyasagar, P. Biology and management of the red palm weevil, rhynchophorus ferrugineus. In Potential Invasive Pests of Agricultural Crops; Peña, J.E., Ed.; CABI: Wallingford, UK, 2013; pp. 1-34.

14. Ashry, I.; Mao, Y.; Al-Fehaid, Y.; Al-Shawaf, A.; Al-Bagshi, M.; Al-Brahim, S.; Ng, T.K.; Ooi, B.S. Early detection of red palm weevil using distributed optical sensor. Sci. Rep. 2020, 10, 3155. [CrossRef]

15. Rasool, K.G.; Khan, M.A.; Aldawood, A.S.; Tufail, M.; Mukhtar, M.; Takeda, M. Identification of proteins modulated in the date palm stem infested with red palm weevil (rhynchophorus ferrugineus oliv.) using two dimensional differential gel electrophoresis and mass spectrometry. Int. J. Mol. Sci. 2015, 16, 19326-19346. [CrossRef]

16. Faleiro, J.; Ferry, M.; Yaseen, T.; Al-Dobai, S. Overview of the Gaps, Challenges and Prospects of Red Palm Weevil Management. In Proceedings of the International Scientific Meeting on 'Innovative and Sustainable Approaches to Control the Red Palm Weevil', Bari, Italy, 23-25 October 2018; pp. 23-25.

17. Zanariah, M.N.; Athirah, N.I. In-service needs for knowledge \& practice and perceived innovative characteristics among frontline officers on integrated pest management extension campaign in terengganu. J. Agrobiotech. 2018, 9, 194-213.

18. Hussain, A.; Rizwan-ul-Haq, M.; Al-Ayedh, H.; AlJabr, A.M. Susceptibility and immune defence mechanisms of rhynchophorus ferrugineus (olivier)(coleoptera: Curculionidae) against entomopathogenic fungal infections. Int. J. Mol. Sci. 2016, 17, 1518. [CrossRef] [PubMed]

19. Al-Ayedh, H.; Hussain, A.; Rizwan-ul-Haq, M.; Al-Jabr, A.M. Status of insecticide resistance in field-collected populations of rhynchophorus ferrugineus (olivier)(coleoptera: Curculionidae). Int. J. Agric. Biol. 2016, 18, 103-110. [CrossRef]

20. Mendesil, E.; Shumeta, Z.; Anderson, P.; Rämert, B. Smallholder farmers' knowledge, perceptions and management of pea weevil in north and north-western ethiopia. Crop Prot. 2016, 81, 30-37. [CrossRef]

21. Pretty, J.; Bharucha, Z.P. Integrated pest management for sustainable intensification of agriculture in asia and africa. Insects 2015, 6, 152-182. [CrossRef]

22. Rossi, V.; Sperandio, G.; Caffi, T.; Simonetto, A.; Gilioli, G. Critical success factors for the adoption of decision tools in ipm. Agronomy 2019, 9, 710. [CrossRef]

23. Sawinska, Z.; Świtek, S.; Głowicka-Wołoszyn, R.; Kowalczewski, P.Ł. Agricultural practice in poland before and after mandatory ipm implementation by the european union. Sustainability 2020, 12, 1107. [CrossRef]

24. FAO. Proceedings of the Scientific Consultation and High-Level Meeting on Red Palm Weevil Management, Rome, Italy, 29-31 March 2017; Shoki Al-Dobai, M.E., Romeno, F., Eds.; FAO: Rome, Italy, 2017; p. 200.

25. FAO. Red Palm Weevil Guidelines on Management Practices; FAO: Rome, Italy, 2020.

26. Ferry, M.; Aldobai, S.; Elkakhy, H. The State of Art of the Control of the Red Palm Weevil. In Proceedings of the Sixth International Date Palm Conference, Abu Dhabi, UAE, 19-21 March 2018; pp. 19-21.

27. Grasswitz, T.R. Integrated pest management (ipm) for small-scale farms in developed economies: Challenges and opportunities. Insects 2019, 10, 179. [CrossRef]

28. Khan, M.; Damalas, C.A. Farmers' knowledge about common pests and pesticide safety in conventional cotton production in pakistan. Crop Prot. 2015, 77, 45-51. [CrossRef]

29. Islam, A.H.M.S.; Schreinemachers, P.; Kumar, S. Farmers' knowledge, perceptions and management of chili pepper anthracnose disease in bangladesh. Crop Prot. 2020, 133, 105139. [CrossRef] 
30. Munyuli, T.; Cihire, K.; Rubabura, D.; Mitima, K.; Kalimba, Y.; Tchombe, N.; Mulangane, E.K.; Birhashwira, O.; Umoja, M.; Cinyabuguma, E. Farmers' perceptions, believes, knowledge and management practices of potato pests in south-kivu province, eastern of democratic republic of congo. Open Agric. 2017, 2, 362-385. [CrossRef]

31. Nampeera, E.L.; Nonnecke, G.R.; Blodgett, S.L.; Tusiime, S.M.; Masinde, D.M.; Wesonga, J.M.; Murungi, L.K.; Baidu-Forson, J.J.; Abukutsa-Onyango, M.O. Farmers' knowledge and practices in the management of insect pests of leafy amaranth in kenya. J. Integr. Pest Manag. 2019, 10, 31. [CrossRef]

32. GAS. Demographics of Saudi Arabia; General Authority for Statistics: Riyadh, Saudi Arabia, 2019.

33. GAS. Detailed Results of Agricultural Census; General Authority for Statistics: Riyadh, Saudi Arabia, 2018.

34. Alqarni, S.; Babiker, A.; Salih, A. Detection, mapping and assessment change in urban and croplands area in al-hassa oasis, eastern region in saudi arabia using remote sensing and geographic information system. Int. J. Geogr. Inf. Syst. 2018, 10, 659-685. [CrossRef]

35. PME. The Meteorology of Al-Hasa; Presidency of Meteorology and Environment: Riyadh, Saudi Arabia, 2019.

36. Allbed, A.; Kumar, L.; Sinha, P. Mapping and modelling spatial variation in soil salinity in the al hassa oasis based on remote sensing indicators and regression techniques. Remote Sens. 2014, 6, 1137-1157. [CrossRef]

37. Alhawas, I.; Hassaballa, A.A. Representation of the spatial association between salinity and water chemical properties in al-hassa oasis. Int. J. Agric. Biol. Eng. 2020, 13, 168-174.

38. Singer, E.; Couper, M.P. Some methodological uses of responses to open questions and other verbatim comments in quantitative surveys. Methods Data Anal. (MDA) 2017, 11, 115-134.

39. McDonald, J.H. Handbook of Biological Statistics; Sparky House Publishing: Baltimore, MD, USA, 2009; Volume 2.

40. Sheskin, D.J. Handbook of Parametric and Nonparametric Statistical Procedures; CRC Press: Boca Raton, FL, USA, 2020.

41. Ali-Bob, M. Management of the red palm weevil rhynchophorus ferrugineus (olivier) using sustainable options in saudi arabia. Arab. J. Plant Protect. 2019, 37, 163-169. [CrossRef]

42. Rach, M.M.; Gomis, H.M.; Granado, O.L.; Malumbres, M.P.; Campoy, A.M.; Martín, J.J.S. On the design of a bioacoustic sensor for the early detection of the red palm weevil. Sensors 2013, 13, 1706-1729. [CrossRef]

43. Muriithi, B.W.; Gathogo, N.G.; Diiro, G.M.; Mohamed, S.A.; Ekesi, S. Potential adoption of integrated pest management strategy for suppression of mango fruit flies in east africa: An ex ante and ex post analysis in ethiopia and kenya. Agriculture 2020, 10, 278. [CrossRef]

44. Massimo, P.; Alberto, R.A.; Roberto, M.; Khalid, A.-R.; Ali, A.-M. Devices to detect red palm weevil infestation on palm species. Precis. Agric. 2018, 19, 1049-1061. [CrossRef]

45. Soroker, V.; Harari, A.; Faleiro, J.R. The Role of Semiochemicals in Date Pest Management. In Sustainable Pest Management in Date Palm: Current Status and Emerging Challenges; Springer: Berlin/Heidelberg, Germany, 2015; pp. 315-346.

46. Mankin, R. Towards User Friendly Early Detection Acoustic Devices and Automated Monitoring for Red Palm Weevil Management. In Proceedings of the Scientific Consultation and High-Level Meeting on Red Palm Weevil Management, Organized by FAO and CIHEAM, Rome, Italy, 29-31 March 2017; pp. $29-31$.

47. Cardim Ferreira Lima, M.; Damascena de Almeida Leandro, M.E.; Valero, C.; Pereira Coronel, L.C.; Gonçalves Bazzo, C.O. Automatic detection and monitoring of insect pests-A review. Agriculture 2020, 10, 161. [CrossRef]

48. Mulley, M.; Kooistra, L.; Bierens, L. High-resolution multisensor remote sensing to support date palm farm management. Agriculture 2019, 9, 26. [CrossRef]

49. Lagos-Ortiz, K.; Salas-Zárate, M.d.P.; Paredes-Valverde, M.A.; García-Díaz, J.A.; Valencia-García, R. Agrient: A knowledge-based web platform for managing insect pests of field crops. Appl. Sci. 2020, 10, 1040. [CrossRef]

50. Steiro, Å.L.; Kvakkestad, V.; Breland, T.A.; Vatn, A. Integrated pest management adoption by grain farmers in norway: A novel index method. Crop Protect. 2020, 135, 105201. [CrossRef]

51. Abd Rabou, A.F.N.; Radwan, E.S. Visual symptoms and control of the red palm weevil (rhynchophorus ferrugineus) in the gaza strip, palestine. Nusant. Biosci. 2017, 9, 322-329. [CrossRef]

52. Donatelli, M.; Magarey, R.D.; Bregaglio, S.; Willocquet, L.; Whish, J.P.; Savary, S. Modelling the impacts of pests and diseases on agricultural systems. Agric. Syst. 2017, 155, 213-224. [CrossRef] 
53. Loko, Y.L.E.; Akohonwe, J.; Toffa, J.; Orobiyi, A.; Assogba, P.; Dansi, A.; Tamò, M. Farmers knowledge, perceptions and management of kersting's groundnut (macrotyloma geocarpum harms) insect pests in Benin. J. Basic Appl. Zool. 2019, 80, 41. [CrossRef]

54. Moinina, A.; Lahlali, R.; MacLean, D.; Boulif, M. Farmers' knowledge, perception and practices in apple pest management and climate change in the fes-meknes region, morocco. Horticulturae 2018, 4, 42. [CrossRef]

Publisher's Note: MDPI stays neutral with regard to jurisdictional claims in published maps and institutional affiliations.

(C) 2020 by the authors. Licensee MDPI, Basel, Switzerland. This article is an open access article distributed under the terms and conditions of the Creative Commons Attribution (CC BY) license (http://creativecommons.org/licenses/by/4.0/). 